\title{
GAMBARAN PENYESUAIAN DIADIK PADA PASANGAN DEWASA MUDA DI AWAL PERNIKAHAN
}

\author{
Pingkan C. B. Rumondor \\ Jurusan Psikologi, Fakultas Psikologi, Bina Nusantara University \\ Jln. Kemanggisan Ilir III No. 45, Kemanggisan, Palmerah, Jakarta Barat 11480 \\ pingkan.cbr@gmail.com
}

\begin{abstract}
Marriage is one of young adulthood's developmental task. The beginning phase of marriage is often beyond expectation of the newlyweds, it is a hard adjustment time for the couples. Therefore, adjustment in this phase is crucial for future marriage quality. The aim of this research is to describe the dyadic adjustment of young adult couples in the beginning phase of their marriage, using Spanier's dimension of dyadic adjustment. This reasearch use qualitative approach with interview and observation as data collection method. This research found that in dyadic consensus, one couple see a disagreement because of different way of thinking. In dyadic cohesion, one couple feel that they are lack of intimacy. In dyadic satisfaction, the couples tend to feel satisfied. While in affectional expression, the couples tend to express affection thruouh physical contact and behaviour that accord with their couple's preference. Areas that could be improved are couple's communication to reach dyadic concensus and couple's intimacy to increase dyadic cohession.
\end{abstract}

Keywords: dyadic adjustment, beginning phase of marriage, young adult

\begin{abstract}
ABSTRAK
Menikah merupakan salah satu tugas perkembangan dewasa muda. Masa awal pernikahan seringkali tidak sesuai harapan pasangan yang baru menikah, bahkan merupakan masa-masa penyesuaian yang sulit bagi pasangan. Oleh karena itu, penyesuaian di masa ini penting bagi kualitas pernikahan di masa depan. Penelitian ini bertujuan mengetahui gambaran penyesuaian diadik pasangan dewasa muda pada masa awal pernikahan dengan menggunakan dimensi penyesuaian diadik Spanier. Penelitian ini menggunakan pendekatan kualitatif melalui metode wawancara dan observasi kepada tiga pasang partisipan. Dalam penelitian ini, ditemukan bahwa dalam dimensi kesepakatan dalam pernikahan, satu pasangan masih mempersepsikan adanya ketidaksepakatan dalam beberapa area yang disebabkan perbedaan pola pikir. Dalam dimensi kedekatan hubungan, satu merasa kurang dekat satu sama lain. Dalam dimensi kepuasan hubungan dalam pernikahan, ketiga pasang partisipan merasa puas dengan pernikahannya. Sedangkan dalam dimensi ekspresi afeksi, ketiga pasangan mengekspresikan kasih sayang melalui kontak fisik serta perilaku yang sesuai dengan preferensi pasangan masing-masing. Area yang dapat menjadi fokus intervensi antara lain cara komunikasi untuk mencapai kesepakatan serta keintiman pasangan untuk menambah kedekatan antar pasangan.
\end{abstract}

Kata kunci: penyesuaian diadik, masa awal pernikahan, dewasa muda 


\section{PENDAHULUAN}

Cerita dongeng seringkali berakhir dengan sebuah pernikahan yang indah antara puteri dan pangeran. Namun pada kenyataannya, pernikahan tidak seindah dan semudah cerita dongeng. Dalam salah satu blog tertulis cuplikan tulisan berikut:

\footnotetext{
"Tahun-tahun pertama pernikahan sempat membuatku putus asa, lelah dan hampir pudar semua rasa cintaku menghadapi karakter suami yang keras dan kasar sedangkan aku bukan tipe orang yang terbiasa dikerasi... Tahun kedua menikah kami hampir bercerai... Saya muak di setiap pertengkaran selalu tersisip kata-kata berpisah dalam kalimat amarahnya...suami terlalu protektif dalam segala gerakku, pesimis dan sensitif..." (/).
}

Penggalan blog yang ditulis berdasarkan pengalaman seorang wanita dewasa muda di atas menggambarkan bahwa seringkali masa awal pernikahan tidak seindah yang dibayangkan oleh pasangan baru. Hal remeh seperti perbedaan cara menekan tabung pasta gigi ternyata menyebabkan kekesalan pada kedua belah pihak. Jika situasi ini tidak ditangani dengan sikap yang tepat dari pasangan maka pernikahan yang diharapkan indah dapat buyar, bahkan dapat memicu perceraian.

Pernikahan ialah salah satu cara memenuhi tugas perkembangan dewasa muda. Seseorang memasuki pernikahan dalam usia yang bervariasi, tetapi sebagian besar pasangan menikah berada pada masa dewasa muda. Masa dewasa muda ialah masa ketika seseorang mengembangkan hubungan intim dan komitmen pada pasangan (Erikson dalam Papalia, Olds, \& Feldman, 2004). Setiap pasangan yang menikah mengharapkan pernikahan yang sukses yaitu pernikahan yang berkualitas dan bertahan lama dengan pasangan mereka (Atwater \& Duffy, 1999).

Kualitas suatu pernikahan dapat dievaluasi dengan melihat proses yang dilalui pasangan dalam pernikahan. Salah satu konsep yang dapat digunakan untuk mengevaluasi kualitas pernikahan ialah penyesuaian diadik (dyadic adjustment) yang dicetuskan Spanier (1976). Spanier mendefinisikan penyesuaian diadik sebagai proses yang bergerak dalam kontinum yang dapat dievaluasi sebagai penyesuaian yang baik atau penyesuaian yang buruk. Penyesuaian pernikahan dan kepuasan pernikahan terkait dengan 50\% laju perceraian di Amerika Serikat, selain itu juga terkait dengan distress individu, kesehatan fisik dan kesejahteraan anak (Lawrence et al., 2009). Oleh karena itu, penting bagi pasangan untuk memiliki penyesuaian yang baik agar pernikahan menjadi berkualitas dan tahan lama. Walaupun tidak ada resep yang ajeg untuk membina pernikahan yang sukses, tetapi Marano (dalam Atwater dan Duffy, 2005) mengumpulkan hasil penelitian mengenai beberapa faktor yang mendukung kesuksesan pernikahan, dari hasil-hasil penelitian tersebut, dapat disimpulkan bahwa komunikasi, manajemen konflik dan keintiman merupakan faktor penting yang dapat menunjang pernikahan yang sukses.

Pada kenyataannya, kegagalan mempertahankan pernikahan merupakan masalah yang sering terjadi di Indonesia beberapa tahun terakhir ini. Menurut data dari Kementerian Agama RI, terdapat 250 ribu kasus perceraian pada tahun 2009 atau sekitar 10 persen dari jumlah pernikahan di tahun yang sama, yaitu sebanyak 2,5 juta. Jumlah tersebut meningkat bila dibandingkan data pada tahun 2008 dimana tercatat ada sekitar 200 ribu perceraian yang terdaftar. Artinya, di Indonesia ada kenaikan sebesar 50 ribu kasus hanya dalam periode setahun (Media Indonesia, April 2010). Kenaikan tersebut memperlihatkan bahwa masalah perceraian ini perlu diberi perhatian khusus.

Perceraian dapat terjadi karena berbagai faktor, Markman, Stanley dan Blumberg (2001) merangkum faktor risiko timbulnya masalah dalam pernikahan yaitu: cara bicara yang negatif, kesulitan berkomunikasi saat mengalami perbedaan pendapat, gagal menghadapi perbedaan pendapat sebagai satu tim, memiliki belief yang tidak realistis tentang pernikahan, memiliki sikap yang berbeda mengenai hal yang penting dan memiliki tingkat komitmen yang rendah. Jika hal tersebut tidak diatasi dengan baik maka dapat timbul konflik yang berakibat gagalnya pernikahan. 
Penelitian lain menunjukkan bahwa konflik dapat timbul sejak masa awal pernikahan. Hasil penelitian Kilis (2006) mengenai dinamika konflik pada masa awal pernikahan menemukan bahwa sumber penyebab konflik ialah adanya diskrepansi antara ekspektansi dan kenyataan, serta adanya perbedaan antar individu yang meliputi: prinsip hidup, cara hidup dan pola pikir. Di samping konflik, penurunan bertahap pada kualitas pernikahan dalam empat tahun pertama (Kurdek dalam Olson \& Defrain, 2006) juga menjadi tantangan dalam mempertahankan pernikahan. Dapat disimpulkan bahwa masa awal pernikahan merupakan masa dimana pasangan menyesuaikan diri dengan perbedaan yang ada serta menemukan cara terbaik untuk memecahkan konflik yang terjadi antara mereka.

Menurut Williams, Stacey \& Carl (2006), masa awal pernikahan ialah 2 hingga 3 tahun pertama sebelum kehadiran anak. Masa ini merupakan masa yang paling sulit bagi pasangan meskipun mereka sebelumnya sudah tinggal bersama dan merasa memiliki hubungan yang baik. Hal ini terjadi karena transisi yang dialami lebih sulit daripada yang diantisipasi oleh pasangan (Olson \& DeFrain, 2006). Sejalan dengan penelitian yang telah disebutkan di atas, pada masa ini seseorang mengalami perubahan-perubahan seperti penyesuaian antara harapan ideal akan pasangan dengan kenyataan yang dijumpai sehari-hari, penyesuaian diri dengan tingkat kemandirian, penyesuaian diri dengan teman dan keluarga dari pasangan, serta pembagian tanggung jawab dalam hal biaya hidup dan pembagian tugas rumah tangga (Williams, Stacey \& Carl, 2006). Perubahan-perubahan tersebut membuat tahun-tahun awal pernikahan sebagai masa penyesuaian yang paling sulit dalam pernikahan (Nichols dalam Harway, 2005).

Melihat latar belakang di atas, maka diperlukan adanya penelitian mengenai gambaran dyadic adjustment yang dialami pasangan di masa awal pernikahan. Pasangan yang akan diteliti merupakan pasangan yang tidak sedang mengalami distress atau gangguan psikologis yang berat dalam pernikahannya. Dari gambaran tersebut dapat disimpulkan mengenai hal-hal yang dapat menjadi fokus intervensi untuk meningkatkan kualitas pernikahan pasangan tersebut. Berdasarkan latar belakang tersebut maka masalah yang akan dijawab dalam penelitian ini dapat dirumuskan sebagai berikut: "Bagaimana gambaran penyesuaian pernikahan pasangan di masa awal pernikahan?” serta “Apa yang menjadi fokus intervensi untuk meningkatkan kualitas pernikahan pasangan di awal pernikahan?”. Hasil penelitian ini diharapkan dapat menjadi masukan bagi pengembangan program intervensi untuk meningkatkan kualitas pernikahan bagi pasangan di masa awal pernikahan.

\section{Pernikahan}

Duvall dan Miller (1985) mendefinisikan pernikahan sebagai hubungan antara pria dan wanita yang diterima secara sosial dan memungkinkan terjadinya hubungan seksual, pengasuhan anak secara legal dan pembagian kerja antara pasangan. Definisi tersebut sejalan dengan definisi pernikahan sebagai hubungan antara wanita dan pria yang diakui secara hukum dan sosial, mencakup hak dan kewajiban seksual, ekonomi, serta sosial dari masing-masing pasangan.

Sama halnya seperti seorang individu mengalami perubahan identitas sesuai dengan siklus kehidupan yang terdiri dari delapan tahap perkembangan (Erikson dalam Duvall \& Miller, 1985), keluarga juga memiliki tahap-tahap perkembangan yang diawali dengan pernikahan. Duvall \& Miller membagi family life cyle ke dalam delapan tahap dimana masing-masing tahap memiliki karakteristik dan tugas perkembangan yang berbeda. Sejalan dengan pembagian tersebut, Williams, Stacey \& Carl (2006) membagi siklus pernikahan menjadi empat fase, yaitu fase awal pernikahan, fase membesarkan anak, fase middle age, dan fase penuaan. Sementara Carter \& McGoldrick (dalam Santrock, 2006) membagi siklus keluarga dalam enam tahap dimulai dari tahap meninggalkan rumah dan menjadi seorang dewasa yang hidup melajang, tahap pasangan yang baru menikah, tahap menjadi orangtua dan keluarga dengan seorang anak, keluarga dengan anak remaja, keluarga dewasa madya dan keluarga lansia. 
Menurut Duvall \& Miller (1985), masa awal perkawinan ialah masa dua setengah tahun pertama perkawinan saat pasangan belum memiliki anak. Masa ini merupakan masa transisi antara kehidupan lajang dengan kehidupan pernikahan. Masa ini penuh dengan proses penyesuaian diri dalam berbagai area kehidupan antara dua individu yang memiliki kepribadian dan latar belakang yang berbeda. Dalam masa ini terdapat beberapa perubahan yang berbeda dengan kehidupan lajang, antara lain: penyesuaian antara harapan ideal dengan keadaan sesungguhnya dari pasangan (Blumstein dalam Williams, Stacey, Carl, 2006), kehilangan kemandirian, penyesuaian diri dengan teman dan keluarga dari pasangan, pembagian tugas dan peran. Selain menyesuaikan diri dengan perubahan di atas, menurut DeGenova \& Rice (dalam DeGenova, 2005) pasangan di awal pernikahan biasanya juga membutuhkan penyesuaian dalam area berikut: pemenuhan dan dukungan emosional, penyesuaian seksual, keuangan terkait dengan pernikahan, pekerjaan dan pencapaian, komunikasi, kewenangan dan pengambilan keputusan, konflik dan pemecahan masalah, moral, nilai dan ideologi.

\section{Penyesuaian Pernikahan (marital adjustment)}

Menurut Atwater \& Duffy (1999) penyesuaian pernikahan ialah perubahan dalam hubungan pasangan selama berjalannya pernikahan. Sejalan dengan definisi tersebut, DeGenova (2005) mendefinisikan penyesuaian pernikahan sebagai proses memodifikasi, beradaptasi dan mengubah pola perilaku dan interaksi pasangan maupun individu untuk mencapai kepuasan maksimun dalam hubungan. Sementara, menurut Lawrence (2009), penyesuaian pernikahan mencakup proses-proses dalam pernikahan seperti keterampilan manajemen konflik dan konsekuensi dari pernikahan, seperti kepuasan pernikahan (marital satisfaction). Kepuasan pernikahan ialah perasaan menyenangkan dan puas dalam pernikahan (Atwater \& Duffy, 2005).

Lebih khusus lagi, Spanier memandang penyesuaian pernikahan sebagai penyesuaian diadik (dyadic adjustment) atau penyesuaian antara dua individu. Penyesuaian diadik didefinisikan sebagai proses yang bergerak dalam suatu kontinum yang dapat dievaluasi berdasarkan kedekatan dengan penyesuaian yang baik atau penyesuaian yang buruk (Spanier, 1976). Spanier mengemukakan bahwa ada beberapa dimensi dalam penyesuaian pernikahan, atau penyesuaian diadik, yaitu: kesepakatan dalam pernikahan (dyadic consensus), kedekatan hubungan (dyadic cohesion), kepuasan hubungan dalam pernikahan (dyadic satisfaction), dan ekspresi afeksi (affectional expression).

\section{Faktor pendukung kesuksesan pernikahan}

Walaupun tidak ada resep yang ajeg untuk membina pernikahan yang sukses, tetapi Marano (dalam Atwater dan Duffy, 2005) mengumpulkan hasil penelitian mengenai beberapa faktor yang mendukung kesuksesan pernikahan. Pertama, faktor utama yang ditemukan dalam penelitian longitudinal pada pasangan yang sangat puas pada pernikahannya ialah kemampuan memecahkan masalah secara bersama-sama. Faktor ini ditemukan pada 2/3 pasangan yang sangat puas dengan pernikahannya. Kedua, faktor yang berperan dalam kelangsungan pernikahan ialah bagaimana pasangan bersenang-senang bersama dan mengingat kembali pengalaman bahagia tersebut. Ketiga, penelitian lain menemukan bahwa salah satu prediktor terbaik untuk pernikahan yang sukses ialah kualitas komunikasi pasangan dalam mengatasi perbedaan dan masalah. Keempat, faktor lain yang mendukung kesuksesan pernikahan ialah affective affirmation atau komunikasi mengenai bagaimana pasangan saling mencintai dan sikap menerima pasangan tanpa syarat. Faktor lain yang juga dapat mendukung pernikahan yang bahagia dan bertahan lama ialah kemampuan empati untuk memahami perasaan pasangan, keseimbangan antara waktu yang dihabiskan bersama dan sendiri, hubungan seksual yang memuaskan dan keinginan bersama untuk melakukan penyesuaian (Schwartz dalam Atwater \& Duffy, 2005). Dari penjabaran di atas dapat disimpulkan bahwa komunikasi, manajemen konflik dan keintiman merupakan faktor penting yang dapat menunjang pernikahan yang sukses. 


\section{METODE}

Penelitian ini menggunakan pendekatan kualitiatif, dimana pendekatan ini melihat realitas sosial sebagai sesuatu yang subjektif dan diinterpretasikan, bukan sesuatu yang berada di luar individu (Poerwandari, 2005). Pendekatan ini mencoba mengungkap data dari perspektif subjek yang diteliti (Poerwandari, 2005). Dyadic adjustment merupakan pengalaman subjektif individu, oleh karena itu sesuai diteliti dengan pendekatan kualitatif. Pengumpulan data dilakukan dengan cara observasi dan wawancara mendalam, menggunakan kerangka dimensi dyadic adjustment menurut Spanier (1976).

Penelitian ini berfokus pada pengalaman subjektif partisipan sehingga jumlah kasus cenderung sedikit. Patton (dalam Poerwandari, 2005) mengemukakan bahwa pengambilan sampel disesuaikan dengan masalah dan tujuan penelitian. Patton juga menyatakan bahwa validitas, kedalaman arti, dan insight yang dimunculkan penelitian kualitatif lebih berhubungan dengan kekayaan informasi dari kasus atau subjek yang dipilih, daripada tergantung pada jumlah subjek. Partisipan dipilih dengan pendekatan purposif, dimana sampel tidak diambil secara acak melainkan mengikuti kriteria tertentu. Jumlah partisipan dalam penelitian ini ialah tiga pasangan atau enam individu (3 laki-laki dan 3 perempuan) pada masa awal pernikahan dengan kriteria sebagai berikut: subjek dalam penelitian ini ialah individu dalam tahap perkembangan dewasa muda yaitu usia 20-40 tahun (Papalia et al., 2004), berada dalam fase awal pernikahan sesuai definisi Duvall \& Miller (1985), yaitu masa dua setengah tahun pertama perkawinan saat pasangan belum memiliki anak, pernikahan tidak berada dalam keadaan distress, terlihat dari skor DAS yang lebih dari 100 (Prouty, Markowski \& Barnes dalam Mamdy, 2007).

Prosedur pemilihan partisipan diawali dengan mencari pasangan yang berada dalam fase awal pernikahan, yaitu baru menikah antara satu bulan hingga dua setengah tahun (Duvall \& Miller, 1985). Proses pencarian dilakukan dengan menghubungi beberapa pasangan yang telah dikenal oleh peneliti dan meminta rekomendasi dari mereka mengenai pasangan baru menikah yang tertarik dengan penelitian ini. Setelah mendapat partisipan, dilakukan beberapa kali pertemuan untuk membina rapport dan melakukan wawancara pada ketiga pasangan. Wawancara dilakukan bersamaan antara suami dan isteri, sehingga dapat dilakukan observasi akan interaksi pasangan tersebut. Setelah itu dilakukan analisis terhadap data yang didapat saat wawancara dan observasi.

\section{HASIL DAN PEMBAHASAN}

Berdasarkan wawancara diketahui bahwa ketiga pasangan memiliki proses dyadic adjustment yang berbeda-beda sehingga hal yang menjadi fokus intervensi untuk meningkatkan kualitas pernikahan juga berbeda.

Pasangan I (Hasan-Risa) sudah menikah selama 2,5 bulan saat penelitian dilakukan. Berdasarkan observasi, mereka tampak dapat menunjukkan cinta dengan menghargai pasangannya, terlihat dari gerak tubuh, cara menatap serta nada suara saat berbicara pada pasangan. Mereka juga sangat bersemangat untuk menjadi lebih baik, menuju sebuah pernikahan mandiri yang mereka dambakan. Namun mereka memiliki perbedaan pola pikir yang menyebabkan mereka cukup sering memandang masalah dari sudut berbeda sehingga menimbulkan perbedaan pendapat. Oleh karena itu, kualitas pernikahan mereka dapat lebih ditingkatkan jika mereka mau merubah cara komunikasi menjadi lebih efektif untuk mengatasi perbedaan dan meningkatkan kualitas pernikahan mereka. Hal ini sangat mungkin dilakukan karena pasangan yang baru menikah cenderung berada dalam periode yang mudah berubah, ketika pola interaksi mereka lebih terbuka pada pengaruh dan perubahan (Behrens \& Sanders; Hawley \& Olson dalam Carrere, Buehlman, Gottman, Coan, \& Ruckstuhl, 2000). 
Pasangan II (Geri-Gina) yang sudah menikah selama 3 bulan merasa mereka memiliki pernikahan yang sudah memuaskan bagi keduanya. Mereka memiliki tujuan bersama, nilai-nilai yang sama dan keyakinan yang kuat terhadap pasangannya. Mereka sudah dapat menunjukkan cinta dengan menghargai pasangannya. Selain itu, mereka juga terbuka terhadap hal-hal yang dapat membuat hubungan mereka menjadi lebih sempurna, misalnya dengan mengikuti penelitian ini. Walaupun begitu mereka merasa kurang intim satu sama lain karena kesibukan mereka. Keintiman ini penting untuk dijadikan fokus intervensi karena keseimbangan antara waktu yang dihabiskan bersama dan sendiri merupakan salah satu faktor yang dapat mendukung pernikahan yang bahagia dan bertahan lama (Schwartz dalam Atwater \& Duffy, 2005).

Demikian juga dengan pasangan III (Toni-Karla) Toni dan Karla yang sudah menikah 2 bulan saat penelitian dilaksanakan memiliki pernikahan yang sudah memuaskan bagi keduanya. Mereka menemukan sosok ideal pada diri pasangan masing-masing. Mereka sudah dapat menunjukkan cinta dengan menghargai pasangannya. Namun mereka memiliki perbedaan dalam menentukan komunikasi yang ideal. Pernikahan Toni dan Karla dapat lebih berkualitas lagi jika mereka mau bekerja sama merumuskan tujuan pernikahan yang konkret dan terkait dengan aspek lain dari pernikahan, serta berusaha melatih cara komunikasi yang lebih efektif untuk mengatasi perbedaan dan meningkatkan kualitas pernikahan mereka.

Pada dimensi kesepakatan, pasangan I (Hasan dan Risa) cenderung memiliki pendapat yang sama mengenai hal-hal terkait keuangan, rekreasi, ibadah, cara penunjukan kasih sayang. Namun mereka tidak selalu sepaham, masih ada protes-protes dari Risa maupun Hasan, khususnya dalam pengambilan keputusan penting di pernikahan mereka seperti memutuskan jenis mobil yang akan dibeli. Menurut Hasan, hal ini terjadi karena perbedaan cara berpikir mereka. Hasan tidak bisa berpikir ganda, cenderung terfokus pada satu tujuan, sementara Risa bisa berpikir ganda dan mengerjakan beberapa hal untuk beberapa tujuan sekaligus. Sementara pasangan II (Gina dan Geri) merasa bahwa setelah menikah mereka memiliki lebih banyak waktu untuk berkomunikasi dibandingkan saat pacaran sehingga hal ini mendukung proses mereka mencapai kesepakatan. Mereka cenderung sepaham dalam masalah perkawinan, seperti keuangan keluarga, rekreasi, agama, filosofi hidup dan tugas-tugas rumah tangga. Pasangan III (Karla dan Toni) merasa cukup sering berkomunikasi dan cukup puas dengan pola komunikasi mereka. Kesamaan pola pikir juga cenderung membuat mereka sepakat dalam hal-hal terkait keuangan, rekreasi, ibadah dan cara menunjukkan kasih sayang.

Pada dimensi kedekatan hubungan, pasangan Hasan-Risa dan Tito-Karla merasa mereka cukup akrab dan sering melakukan kegiatan bersama. Hasan dan Risa saat ini merasa dekat satu sama lain. Hal ini terasa sangat berbeda dari masa pacaran karena setelah menikah mereka bisa menghabiskan lebih banyak waktu bersama di rumah, sehingga lebih banyak waktu untuk mengobrol. Selain itu, mereka memiliki cara untuk meningkatkan keintiman, yaitu dengan membangkitkan keromantisan seperti awal berpacaran, yaitu dengan bercanda, mengingat kembali kejadian yang lucu atau kejadian saat mereka berhasil berbaikan setelah melalui pertengkaran. Sementara Karla saat ini merasa dekat dengan Toni, ia merasa Toni selalu ada untuk menemani dirinya. Bahkan saat Toni berada di kantor dan sedang rapat, ia masih dapat berbincang melalui pesan singkat di telepon. Terlebih saat Karla sedang hamil, Toni selalu siaga menemani Karla dalam memeriksakan kandungan ke dokter. Sementara bagi Toni, kesamaan pola pikir dalam memandang permasalahan membuat dirinya merasa semakin intim dengan Karla. Selain itu mereka juga sering melakukan kegiatan bersama, yaitu pergi ibadah bersama serta berjalan-jalan dan makan di restoran bersama minimal satu minggu satu kali, seperti saat mereka masih berpacaran. Saat di rumah, mereka juga sering menonton DVD bersama.

Namun Geri-Gina merasa mereka sulit menemukan waktu berkualitas untuk bertukar pikiran serta membangun keintiman di tengah kesibukan mereka. Geri dan Gina merasa saat ini mereka lebih dekat satu sama lain dibandingkan saat pacaran. Menurut mereka hal ini karena mereka tinggal serumah sehingga lebih sering bertemu. Mereka juga sering melakukan kegiatan bersama. Walaupun 
sering bersama-sama tetapi Gina merasa kurang waktu untuk berdua saja dengan Geri karena setiap kali mereka berdua pasti ada orang lain. Gina merasa ia membutuhkan lebih banyak waktu untuk berbicara berdua saja dengan Geri. Mereka biasanya menikmati keintiman berdua saat akan istirahat malam serta sedang dalam perjalanan di mobil. Kesulitan memiliki waktu intim ini terkait area penyesuaian pernikahan pada pasangan di awal pernikahan (DeGenova \& Rice dalam DeGenova, 2005), ketika mereka masih dalam tahap menyesuaikan jam kerja, aktifitas sosial, dan acara keluarga dengan kegiatan mereka berdua.

Pada dimensi kepuasan hubungan, ketiga pasangan mengungkapkan kepuasan dalam hubungan mereka. Walaupun masih terdapat perbedaan pendapat serta pola pikir tetapi ketiga pasangan memiliki komitmen yang kuat terhadap kelanjutan pernikahan mereka. Kepuasan hubungan ini dapat terjadi karena ketiga pasangan memiliki keinginan bersama untuk melakukan penyesuaian. Dimana hal tersebut merupakan salah satu faktor yang mendukung pernikahan yang bahagia (Schwartz, 2002, dalam Atwater \& Duffy, 2005).

Pada dimensi ekspresi afeksi, ketiga pasangan telah puas dengan cara-cara menunjukkan afeksi dan cara memenuhi kebutuhan seksual yang telah mereka sepakati bersama. Setiap pasangan menunjukkan afeksi dengan cara yang berbeda-beda. Hasan mengekspresikan afeksi pada Risa dengan membelai rambut Risa, mencium Risa dan memanggil dengan panggilan kesayangan. Demikian juga Risa, ia mengekspresikan afeksi dengan mengelus punggung Hasan dan memijat tubuh Hasan. Sementara Geri mengekspresikan afeksi kepada Gina dengan cara membelai Gina, dan Gina menunjukkan afeksi dengan cara memijat Geri serta sesekali mencium Geri secara tiba-tiba. Karla mengekspresikan afeksinya pada Toni dengan cara memijat dan menemani Toni saat menonton sepak bola, hal yang sebenarnya tidak disukai oleh Karla. Sementara Toni mengekspresikan afeksinya dengan cara memegang tangan, memeluk serta mencium Karla. Aspek ini bukanlah fokus potensi masalah dari ketiga pasangan sehingga tidak perlu untuk diubah.

\section{PENUTUP}

Berdasarkan wawancara dapat terlihat bahwa masa awal pernikahan merupakan masa yang penuh dengan penyesuaian di berbagai area. Dalam dimensi kesepakatan dalam pernikahan, satu pasangan sesekali berselisih paham dan memiliki masalah yang belum terselesaikan, masih mempersepsikan adanya ketidaksepakatan dalam beberapa area. Dalam dimensi kedekatan hubungan, satu pasangan merasa kurang intim satu sama lain karena kesibukan mereka dalam pekerjaan serta aktifitas sosial. Dalam dimensi kepuasan hubungan dalam pernikahan, ketiga pasang partisipan merasa puas dengan pernikahannya. Sedangkan dalam dimensi ekspresi afeksi, ketiga pasangan mengekspresikan kasih sayang melalui kontak fisik dan perilaku yang sesuai dengan preferensi pasangan masing-masing. Walaupun ketiga pasangan partisipan memerasa puas dengan pernikahannya, namun masih ada dimensi yang dapat ditingkatkan oleh pasangan. Dimensi yang masih dapat ditingkatkan ialah dimensi kesepakatan dalam pernikahan serta kedekatan hubungan. Penelitian selanjutnya dapat mengembangkan serta meneliti efektifitas program intervensi penguatan pernikahan bagi pasangan dewasa muda yang baru menikah. Berdasarkan gambaran penyesuaian diadik ketiga pasang partisipan, area yang dapat menjadi fokus intervensi antara lain cara komunikasi untuk mencapai kesepakatan serta keintiman pasangan untuk menambah kedekatan antar pasangan. Pada penelitian ini, usia pernikahan pasangan berkisar antara 2-3 bulan, penelitian selanjutnya dapat melakukan penelitian kuantitatif untuk melihat perbedaan penyesuaian diadik pasangan dengan rentang usia pernikahan pasangan yang berbeda-beda sehingga dapat dilihat masa awal yang memiliki penyesuaian paling berat. Setelah itu dapat diadakan penelitian lanjutan mengenai intervensi yang efektif untuk meningkatkan kualitas pernikahan. 


\section{DAFTAR PUSTAKA}

Atwater, E., \& Duffy, K. G. (1999). Psychology for Living : Adjustment, Growth, and Behavior Today $\left(6^{\text {th }}\right.$ ed.). New Jersey: Prentice-Hall.

Atwater, E., \& Duffy, K. G. (2005). Psychology for Living : Adjustment, Growth, and Behavior Today ( $7^{\text {th }}$ ed.). New Jersey: Prentice-Hall.

Baltyra.com (2010). Family Corner: Lima Tahun Pernikahanku. Diunduh dari http://baltyra.com/2010/02/04/lima-tahun-pernikahanku

Carrere, S., Buehlman, K. T., Gottman, J. M., Coan, J. A. \& Ruckstuhl, L. (2000). Predicting marital stability and divorce in newlywed couples. Journal of Family Psychology, 14, 1, 42-58.

DeGenova, M. K. (2005). Intimate relationships, Marriage and Families. Boston: McGraw-Hill.

Duvall, E. M., Miller, B. C. (1985). Marriage and Family Development $6^{\text {th }}$ edition. London: Harper \& Row.

Harway, M. (2005). Handbook of Couples Therapy. New Jersey: John Wiley \& Sons.

Kilis, G. (2006). Dinamika Konflik Suami Istri pada Masa Awal Perkawinan. Tugas Akhir, tidak diterbitkan. Depok: Universitas Indonesia.

Lawrence, E., Barry, R.A., Langer, A., Brock, R.L. (2009). Marital Satisfaction, Assesment of. Encyclopedia of Human Relationships. SAGE Publications. Diunduh tanggal 3 April 2010 dari http://www.sage-ereference.com/humanrelationships/Article_n330.html.

Mamdy, S. Z. (2007). Penyesuaian pernikahan pada pasangan yang baru memiliki anak pertama. Tugas akhir, tidak diterbitkan. Depok: Universitas Indonesia.

Markman, H. J., Stanley, S. M., Blumberg, S. L. (2001). Fighting for Your Marriage: The Best Selling Marriage Enhancement \& Divorce Prevention Book. California: Jossey Bass.

Papalia, D. E., Olds, S. E., Feldman, R. D. (2004). Human Development: 9th ed. New York: McGrawHill.

Poerwandari, K. (2001). Pendekatan Kualitatif untuk Penelitian Perilaku Manusia. Depok: LPSP3 UI.

Olson, D. H., DeFrain, J. (2006). Marriages \& Families: Intimacy, Diversity and Strengths $5^{\text {th }}$ edition. Boston: McGraw-Hill.

Santrock, J. W. (2006) Life-Span Development. Boston: McGraw Hill

Spanier, G. B. (1976). Measuring Dyadic Adjustment: New Scales for Assessing the Quality of Marriage and Similar Dyads. Journal of Marriage and the Family, Vol. 38, No. 1. (Feb., 1976), pp. 15-28.

Williams, B. K., Stacey, C. S., Carl, M. W. (2006). Intimate Relationship: Practical Introduction. Boston: Pearson. 


\section{RIWAYAT PENULIS}

Pingkan C. B. Rumondor lahir di kota Jakarta pada 22 Maret 1985. Penulis menamatkan pendidikan S2 di Universitas Indonesia dalam bidang psikologi klinis dewasa pada tahun 2010. Saat ini bekerja sebagai dosen di Universitas Bina Nusantara. Penulis aktif di HIMPSI dan Ikatan Psikologi Klinis sebagai anggota. 